\title{
The effect of reserpine on oviposition in the hen
}

\author{
Kousaku TANAKA and Atsushi NAKATSU \\ (Faculty of Agriculture, Kyushu University, Fukuoka-shi)
}

(Received for Publication on August 18, 1971)

The effects of adrenergic and cholinergic drugs on oviposition or egg formation in the hen have been investigated by several workers. STURKIE and WeIss ${ }^{17}$ ) showed that the intramuscular injection of acetylcholine induced premature oviposition and ephedrine sulfate caused delayed oviposition up to 24 hours when administered at the time an egg was in the uterus. In the extensive studies on the effect of various drugs on the chicken oviduct Weiss and STURKiE ${ }^{20}$, demonstrated that the administration of histamine also caused premature oviposition. However, it was shown that ephedrine sulfate, injected into normal hens, decreased the shell weight and thickness (Weiss, ${ }^{19}$; Sturkie et al. ${ }^{18}$ ). Polin and SturkiE ${ }^{15}$ ) used ephedrine sulfate to prevent premature oviposition in one hen that consistently laid eggs without shells and reported that the calcified egg with below normal shell weight was laid by the hen after subcutaneous injection of the drug.

Reserpine is a tranquilizer and hypotensive agent (Plummer et al. ${ }^{14}$ ) ) which has been shown to influence uterine smooth muscle activity $\left(\mathrm{CLEGG}^{8}\right)$ ). BENNETT and $\mathrm{KENDLE}^{2}$ ) observed the arrest of egg transport in the mouse oviduct following treatment with reserpine, and further investigations indicated that changes in hormone secretion are not solely responsible for this action of reserpine (KENDLE and BENNETT ${ }^{9}$ ) and that the arrest of egg transport can be prevented by housing mice at elevated environmental temperatures (KENDLE and BENNETT ${ }^{101}$ ).

The present experiments were designed to investigate whether the administration of reserpine has any adverse effect on oviposition of the hen's egg.

\section{Materials and Methods}

White Leghorn hens in active egg production were used in this study. They were maintained in individual cages and received artificial light of a 14-hour photoperiod, and time of oviposition was recorded from $8 \mathrm{AM}$ to $5 \mathrm{PM}$ for at least 4 weeks before any hen was selected for a test. A stock solution containing $5 \mathrm{mg}$ per $\mathrm{m} l$ of reserpine was prepared as described by BENNETT and KENDLE21. A similar solution without the reserpine was prepared as a vehicle control.

Various dose levels of reserpine, ranging from 1 to $5 \mathrm{mg}$ per hen, were administered by intramuscular or intraperitoneal injection. The effect of the drug on oviposition in the hens with either a palpable hard-shelled egg in the uterus ( 3 to 4 hours before expected oviposition) or a soft-shelled egg in the uterus ( 2 to 3 hours after an egg entered the uterus) was then examined.

A comparative study was also conducted to examine whether the administration of the drug had any adverse effect on the time required for the passage of egg through the anterior oviduct (from ovulation to entrance into the uterus). Two dose levels of reserpine ( $2 \mathrm{mg}$ and $5 \mathrm{mg}$ ) were administered to hens 2 hours before expected ovulation. Palpation 


\section{TANAKa - NAKatsU}

Table 1. Effects of intramuscular and intraperitoneal injections of $5 \mathrm{mg}$ reserpine on oviposition of the hen's egg (preliminary experiment)

\begin{tabular}{lccccc}
\hline $\begin{array}{c}\text { Route of } \\
\text { injection }\end{array}$ & $\begin{array}{c}\text { No. hens } \\
\text { treated }\end{array}$ & $\begin{array}{c}\text { Kind of egg } \\
\text { at time of } \\
\text { treatment }\end{array}$ & $\begin{array}{c}\text { No soft eggs } \\
\text { laid on day } \\
\text { of treatment }\end{array}$ & $\begin{array}{c}\text { No. eggs } \\
\text { showing } \\
\text { delay* } \\
\text { (over 1 day) }\end{array}$ & Remarks \\
\hline $\begin{array}{c}\text { Intramuscular } \\
\text { injection }\end{array}$ & 5 & Soft** & 2 & 2 & $\begin{array}{c}\text { One died on next } \\
\text { day of treatment; } \\
\text { hard-shelled egg was } \\
\text { found in uterus }\end{array}$ \\
\cline { 2 - 6 } & 3 & Hard*** & - & 3 & \\
\hline $\begin{array}{c}\text { Intraperitoneal } \\
\text { injection }\end{array}$ & 5 & Soft & 3 & 1 & $\begin{array}{c}\text { One laid a hard- } \\
\text { shelled egg on next } \\
\text { day of treatment }\end{array}$ \\
\hline
\end{tabular}

* All delayed eggs were normal in appearance

** Reserpine was injected 2 to 3 hours after an egg entered the uterus

*** Reserpine was injected 3 to 4 hours before expected oviposition of a terminal egg of the clutch

Table 2. Effect of varying dose levels of reserpine on oviposition, administered by intramuscular injection to hens with a soft-shelled egg in the uterus

\begin{tabular}{cccccc}
\hline $\begin{array}{c}\text { Dose per hen } \\
(\mathrm{mg})\end{array}$ & $\begin{array}{c}\text { No. hens } \\
\text { treated }\end{array}$ & $\begin{array}{c}\text { No. soft-shelled } \\
\text { eggs laid on day } \\
\text { of treatment }\end{array}$ & $\begin{array}{c}\text { No. hard-shelled } \\
\text { eggs laid on next } \\
\text { day of treatment }\end{array}$ & $\begin{array}{c}\text { No. eggs } \\
\text { showing delay } \\
\text { (over 1 day) }\end{array}$ & No. deaths* \\
\hline 1 & 10 & 2 & 5 & 3 & 1 \\
2 & 10 & 2 & 5 & 3 & 2 \\
3 & 10 & 2 & 4 & 2 & $3^{* *}$ \\
4 & 10 & 4 & 4 & 2 & 2 \\
5 & 10 & 4 & 22 & 10 & 12 \\
Total & 50 & 14 & 10 & 0 & 0 \\
\hline $\begin{array}{l}\text { Vehicle } \\
\text { control }\end{array}$ & 10 & 0 & & & 2 \\
\hline
\end{tabular}

* Number of hens which died within 5 days following treatment

** Two hens each died before expulsion of the egg in the uterus

through the cloaca, starting at 3 hours after expected ovulation, was repeated at 20 -minute intervals until an egg entered the uterus.

\section{Results and Discussion}

In a preliminary study, $5 \mathrm{mg}$ of reserpine was administered at a time when a terminal hard-shelled egg of the clutch or a soft-shelled egg was in the uterus. As shown in Table 1, a single intramuscular injection of reserpine when a soft-shelled egg was in the uterus caused premature expulsion of eggs within several hours in two out of five hens treated, while two showed delayed oviposition ( 1 and 3 days of delay). One died on the next day of the treatment in which case a hard-shelled egg, normal in appearance, was found in the uterus by post-mortem examination. Similarly, intraperitoneal injection of reserpine resulted in either premature or delayed oviposition. On the other hand, the same dose of the drug caused delayed oviposition for much as 1 to 4 days in all cases when given to hens with a terminal hard-shelled egg of the clutch. It was observed that all hens so treated tended to squat down or push the head into a corner, and showed severe diarrhea.

In the detailed study, when an egg was in the uterus, various dose levels of reserpine 
Effect of reserpine on oviposition

Table 3. A comparison in the egg weight and shell thickness between hard-shelled eggs laid before and after administration of reserpine

\begin{tabular}{|c|c|c|c|c|c|}
\hline \multirow{2}{*}{$\begin{array}{l}\text { Period of } \\
\text { delay } \\
\text { (day) }\end{array}$} & \multirow{2}{*}{$\begin{array}{l}\text { No. hens } \\
\text { treated }\end{array}$} & \multicolumn{2}{|c|}{$\begin{array}{c}\text { Average egg weight } \\
(\mathrm{g})\end{array}$} & \multicolumn{2}{|c|}{$\begin{array}{l}\text { Average shell thickness } \\
(\mathrm{mm})\end{array}$} \\
\hline & & $\begin{array}{c}\text { Before } \\
\text { treatment* }\end{array}$ & $\begin{array}{c}\text { After } \\
\text { treatment }\end{array}$ & $\begin{array}{l}\text { Before } \\
\text { trcatment* }\end{array}$ & $\begin{array}{c}\text { After } \\
\text { treatment }\end{array}$ \\
\hline 0 & 20 & 53.3 & 51.4 & 0.32 & 0.26 \\
\hline 1 & 7 & 49.7 & 48.3 & 0.32 & 0.28 \\
\hline 2 & 6 & 51.6 & 50.4 & 0.29 & 0.29 \\
\hline
\end{tabular}

* Eggs laid on 1 day or 2 days before treatment

were administered in a similar manner as that described for the preliminary study. Table 2 shows the results, summarized from two separate experiments. Groups of five hens each were treated in each experiment. Fourteen out of a total number of fifty hens treated with reserpine expelled soft-shelled eggs on the day of the treatment and twenty-two laid hard. shelled eggs on the next day. Ten showed delayed oviposition, persisting for as much as 1 to 3 days beyond the expected time of normal oviposition, although these delayed eggs appeared perfectly normal. Under the conditions of this study no apparent difference in the incidence of either premature or delayed oviposition was observed among the dose groups. The control had a normal laying pattern.

Toxic reactions to reserpine, such as severe diarrhea and asthenia or ataxia subsequently led to death in some cases, were noted at all dose levels. Mortality affected by the drug tended to increase as the dose level increased up to $4 \mathrm{mg}$. Similar reactions to reserpine have been reported other animals (EARL'). On the other hand, reduction of egg production by administration of reserpine has been reported for the chicken (GILBREATH et al. ${ }^{6}$ ) and for

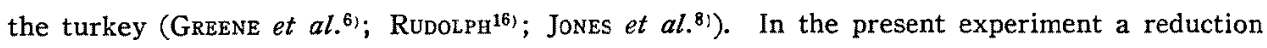
of egg production, and atrophy of the oviduct and the ovaries were observed by post-mortem examination. Such disturbance of the functional reproductive system affected by reserpine was not surprising since reserpine has been reported to interfere with the release of pituitary ovulating hormones in the rat (BARRACLOUGH and SAWYER ${ }^{1 /}$; Hopkins and PINCUs ${ }^{\prime \prime}$ ) and to induce atrophy of the reproductive organs in the rat (KHAZAN et al. ${ }^{11}$; LABHSETWAR ${ }^{12}$ ).

Also, the incidence of delayed oviposition induced by reserpine was not unexpected in view of its inhibitory effect on smooth muscle activity in the guinea-pig uterus $\left(\mathrm{CLEGG}^{3)}\right)$, arrest of egg transport in the mouse oviduct (BenNetT and KENDLE ${ }^{2)}$; Kende and BenNetT ${ }^{9)}$; KendeE and BenNeTT ${ }^{10}$ ) ) and inhibition of oxytocin release (MOON and TURNeR ${ }^{131}$ ). However, the mechanism by which premature oviposition is induced after administration of reserpine is unknown at present.

Table 3 shows the weight and thickness of the hard-shelled eggs laid on the next day of treatment or delayed for 1 day and 2 days, compared to those of the eggs normally laid on 1 day or 2 days prior to treatment. The data indicate that the weight and shell thickness of eggs laid after treatment are comparable to those of the eggs laid before treatment. This suggests that the addition of uterine fluid into the egg and calcification takes place normally after administration of reserpine. Additional calcification during the prolonged periods of stay of the eggs in the uterus was not demonstrated as far as shell thickness was concerned.

A trial was done to investigate the effect of reserpine on the rate of passage of the egg 
Table 4. Effect of reserpine on the rate of passage of the egg through the oviduct down to the uterus after ovulation

\begin{tabular}{ccc}
\hline \hline $\begin{array}{c}\text { Dose per } \\
\text { hen* } \\
(\mathrm{mg})\end{array}$ & $\begin{array}{c}\text { No. hens } \\
\text { treated }\end{array}$ & $\begin{array}{c}\text { Average time required } \\
\text { for passage } \\
\text { (hour) }\end{array}$ \\
\hline 2 & 7 & 6.7 \\
5 & 10 & 6.6 \\
$\begin{array}{l}\text { Vehicle } \\
\text { control }\end{array}$ & 4 & 4.8 \\
\hline * Reserpine was administered by intramuscular injec- \\
tion 2 hours before expected ovulation
\end{tabular}

through the anterior oviduct. When $2 \mathrm{mg}$ and $5 \mathrm{mg}$ of reserpine were administered 2 hours before expected ovulation, the times required for the passage of the egg through the oviduct down to the uterus after ovulation were approximately 6.7 and 6.6 hours respectively, indicating that it takes about 2 hours more than in the control (Table 4). However, this 2 hours delay may not always mean real differences since detection of the actual time of ovulation within several minutes was impossible under the condition of this experiment.

\section{Summary}

The present experiments were conducted to investigate whether the administration of reserpine has any adverse effect on oviposition of the hen's egg.

White Leghorn hens in active egg production were used and maintained in individual cages, receiving artificial light of a 14-hour photoperiod. Various dose levels of reserpine of 1 to $5 \mathrm{mg}$ per hen were administered by a single injection when an egg was in the uterus. The results obtained are summarized as follows.

In a preliminary study, intramuscular or intraperitoneal injection of $5 \mathrm{mg}$ reserpine, administered 2 to 3 hours after an egg entered the uterus, caused either premature or delayed oviposition. The same dose level of the drug induced delayed oviposition for as much as 1 to 4 days when given 3 to 4 hours before expected oviposition of a terminal hard-shelled egg of the clutch.

In the detailed study, various dose levels of reserpine ranging from 1 to $5 \mathrm{mg}$ per hen were admidistered by intramuscular injection when a soft-shelled egg was in the uterus, and caused either premature or delayed oviposition at any of the dose levels. The period of the delay induced by reserpine varied from 1 to 3 days. Average weight and shell thickness of these delayed eggs were proved to be normal as compared to the eggs laid 1 day or 2 days before the treatment. It was observed, however, that all hens so treated tended to squat down or push the head into a corner, and showed severe diarrhèa.

When $2 \mathrm{mg}$ and $5 \mathrm{mg}$ of reserpine were administered 2 hours before expected ovulation, the time required for the passage of the egg through the oviduct down to the uterus after ovulation tended to take approximately 2 hours more than in the control.

\section{References}

1) Barraclough, C.A. and C.H. Sawyer (1957) Endocrinology, 61: 341-351.

2) Bennett, J.P. and K. E. Kendle (1967) J. Reprod. Fert., 13: 345-348.

3) CleGG, P.C. (1963) J. Physiol., 169: 73-90. 
4) Earl, A.E. (1956) J. Amer. Vet. Med. Assoc., 129: 227-233.

5) Gilbreath, J.C., L. F. Garvin and Q. B. Welch (1959) Poultry Sci., 38: 535-538.

6) Greene, D.E., R.C. Eaton, H. L. Wilke and R. M. Bethke (1961) Poultry Sci., 40: 14101411.

7) Hopkins, T.F. and G. Pincus (1963) Fedn Proc. Fedn. Amer. Socs. Exp. Biol., 22: 506.

8) Jones, J. M., J.C. Gilbreath and M.A. Maloney (1966) Poultry Sci., 45: 713-720.

9) Kendee, K. E. and J.P. Bennett (1969) J. Reprod. Fert., 20: 429-434.

10) Kendee, K. E. and J.P. Bennett (1969) J. Reprod. Fert., 20: 435-441.

11) Khazan, N., F. G. Sulman and H. Z. Winnik (1960) Proc. Soc. Exp. Biol. Med., 105: 201-204.

12) Labhsetwar, A.P. (1967) Endocrinology, 81: 357-362.

13) Moon, R. C. and C. W. Turner (1959) Proc. Soc. Exp. Biol. Med., 101: 332-335.

14) Plummer, A. J., A. Eart, J.A. Schneider, J. Trapold and W. Barret (1954) Ann. N. Y. Acad. Sci., 59: 8.

15) Polin, D. and P.D. Sturkie (1955) Poultry Sci., 34: 1169-1170.

16) Rudolph, J. W., J.C. Gilbreath and R. D. Morkison (1962) Poultry Sci., 41: 184-187.

17) Sturkie, P.D. and H.S. Weiss (1950) Poultry Sci., 29: 781.

18) Sturkie, P.D., H.S. Weiss and R.K. Ringer (1954) Poultry Sci., 33: 18-24.

19) WeIss, H.S. (1951) Ph. D. Thesis. Rutgers Univ., New Jersey (quoted from Polin and STURKIE, 1955).

20) Weiss, H.S. and P.D. Sturkie (1952) Poultry Sci., 31: 227-231.

\section{鶏の放卵におよぼすレセルピンの影響 \\ 田中耕作・中津篤 \\ (九州大学農学部)}

レセルピンの放卵におよぼす影響ならびに卵の卵管内 通過時間を検索するために本実験を行なった，供試雌鷄 は白色レグホーンを用い，1日 14 時間の点燈下で飼育 した. 産卵時刻は午前 8 時から 午後 5 時まで毎日記録 し，実験開始のすくなくとも 4 週間前加継続して行な った.レセルピンは BENNETT and KENDLE3) の方法に よって調製し，1羽あたり $1 \sim 5 \mathrm{mg}$ を筋肉あるいは腹 腔内に注入した。

予借害駿として，子宮に卵が到趭してからら 2-3 時間後 に $5 \mathrm{mg}$ のレセルピンを筋肉および腹腔内に注入したと ころ, ある個体は軟卵を放出し，他の個体については放 卵の遅延が認就らた。一方, クラッチの最終卵の場 合, 推定放卵時刻の 3-4 時間前にレセルピンを筋注した 3 例ではすべて 1 日以上（1-4 日）放即が遅延した。

子宮に軟眆が存在する時期に 1-5 mg のレセルピンを
各 10 羽あて筋注した結果， $4 \mathrm{mg}$ 投与区を除き各区と も軟卵の放出怙よび放卵の迤延が観察され，全投与羽数 の $28 \%$ は軟卵の放出を，宗た $20 \%$ は放卵の荤延（1-3 日）が誘起されたが，それら現象と投与量との間に注一 定の傾向は認められなかった。 な杺，1日以上放卵が幄 延した卵の卵殻厚は投与前に産出した卵のそれに比較し て差はなく，外見上も正常䀦であった。一方，本実験条 件において，レセルピン投与は例外なく下湟之衰弱をと もない，投与量の增加にしたがってその影響は強く現わ れる傾向が観察された。

推定排卵時刻の 2 時間前にレセルビン $2 \mathrm{mg}$ おうび $5 \mathrm{mg}$ を筋注し，その後排卯した即が子宮に到達するま での時間を観测したところ，卵管通過に要寸る時間は両 投与区とも対照に比較して約 2 時間長くなる傾向がみら れた。 